\title{
An Alternative Paradigm for Urban Development
}

\section{Kamil Khan Mumtaz}

For an increasing number of people around the world, habitation is not a question of good or bad architecture but of shelter, food, health and economic survival, a question of political empowerment, domination and the control over resources, and ultimately a question of criteria and goals of "development" and "progress".

With their heroic manifestoes, at the beginning of the century the modern movement had set out to transform the world. Architects, the champions of industry and the new mass production technologies were to bring prosperity, happiness and joy to all mankind. With mechanised production of buildings and new modes of transpiration we were to build clean, healthy, well designed, comfortable and aesthetically satisfying new cities. At the center of much of these dreams were the habitation $s$ of the common man. Yet today, at the close of the century after some remarkable "progress" and "development" and despite a profusion of ingenious buildings by a galaxy of brilliant architects, the world, the real world inhabited by a very large section of humanity, has been transformed not into the promised paradise but into a living hell.

"If the future city is simply an extrapolation of current trends, then for much of the world's urban population, their habitat of tomorrow will secure for them nothing more than a shelter within an illegal settlement and an insecure job that provides an inadequate income. These shelters will be made of temporary materials, with whole households cramped into a single small room, often on land sites subject to flooding, with little or no provision of water, sanitation, drainage, garbage removal and health care. This is the reality for some 600 million urban dwellers around the world."

This phenomenon has emerged as the dominant reality in much of the Third World in the twentieth century, and in most cases has become progressively more acute during the last fifty years. Simply stated, it is a combination of rapid population growth; urbanisation; impoverishment; and a failure of the existing state structures to deliver the services needed by these communities. But the collateral damage of "development" has not

\footnotetext{
* Paper presented at a conference of the International Union of Architects held at Barcelona, 1996.

${ }^{1}$ David Satterthwaite, "City Scan” in Down to Earth, February 29, 1996.
} 
been limited to the Third World. The impact of "science run wild" is now being felt even in the most technologically advanced societies.

In the 1995 Reith Lectures, Richard Rogers emphasised that the social problems and ecological crises, generated by contemporary cities and technologies, are closely inter-linked. He argued that "the world's environmental crisis is being driven by our cities" and that "we have to define sustainability in 'social and cultural' terms, as well as in 'environmental and economic' ones.”2

"We are perhaps the first generation to face the simultaneous impact of expanding populations, depletion of resources and erosion of the environment. All this is common knowledge and yet, incredibly industrial expansion carries on regardless and pollution is set to mushroom."

"The essential problem is that cities have been viewed in instrumental or consumerist terms. Those responsible for them have tended to see it as their role to design cities to meet private material needs, rather than to foster public life. The result is that cities have been polarised into communities of rich and poor and segregated into ghettos of single-minded activity - the Business Park, the Housing Estate, the residential suburb - or worse still, into giant single-function buildings like Shopping Centres with their own private streets (which lead nowhere), built in."

Technology has indeed increased production of commodities and material wealth. It has also provided more and more efficient means for the transfer of this wealth over greater and greater distances. As distances between the consumer and the producer have increased so also have the number of middlemen between them who have expropriated increasingly greater shares of the wealth produced. Thus technological development has also resulted in an increase in the rate of exploitation.

Development in communications and military technologies have enhanced man's ability to dominate his fellow man, to manipulate and control greater and greater numbers of people over vaster and vaster distances and territory. Thus as power structures have expanded in size and complexity, the local ruling elite have realigned their allegiances with increasingly bigger, more powerful and distant overlords. In the process traditional social hierarchies based on personal relationships of family, kinship, clan and community, have been replaced by monstrous state bureaucracies and relations of money.

\footnotetext{
${ }^{2}$ Sir Richard Rogers, “Cities for a Small Planet”, BBC Radio 4: the 1995 Reith Lectures.
} 
With the concentration of more and more wealth in the centers of trade and commerce, and with the development of transportation technologies, the size and scale of cities and buildings have grown to inhuman scales and monstrous proportions. In these monster-cities the majority of the urban poor have managed to house themselves, as they have always done, by evolving appropriate building methods and forms, and relying on indigenous resources within the community for financing technical skills and building materials. But the quality of their habitations has been steadily declining as modernisation has destroyed the existing base of indigenous knowledge systems and building practices, particularly those which catered to the construction of the habitat for the urban poor.

Industrially produced building materials have all but eliminated the use of indigenous materials and modern educational institutions have destroyed the previously existing systems of transmitting knowledge and skills from master to apprentice. Indeed all the systems: local governance, urban management, justice finance, and social infrastructure including education, health etc. Which were until recently based in the community, were small scale, familiar and accessible, have become increasingly remote, alien, impersonal and inaccessible to the majority of the urban poor.

Without access to the banking system, the poor have evolved their own community based systems of savings and finance. Not being able to afford industrially produced materials they have developed their own backyard enterprises which provide low-grade but affordable materials and construction services. Denied access to officially developed urban land, they have illegally occupied the "terrain vague" in and around the cities, under the protective umbrellas of self-appointed networks of agents and operators who are often sufficiently organised to extract public services such as water and electricity from the local authorities. Not having access to the stateowned, public health and education systems they have developed their own neighborhood schools and health services.

While the services provided by these informal networks often cost more than the "official" rates, they are at least accessible, and they do deliver. If the failure of the networks to provide a better quality of life is due to their inability to access the formal sector institutions and structures of the modern state, their successes, however limited, are due to their rootedness in the local culture and community. But the legally recognised professional architect has been isolated from this culture and community by his modern education. He no longer speaks the same language as the building craftsman. He has been marginalised and made irrelevant to the reality that surrounds him. 
For a century now architects and planners, along with other professions in medicine, agronomy, education, economics, have promoted the myth of the technological utopia. Making a fetish of the machine, we have planned our cities for the motor car and designed our buildings to accommodate lift shafts and air-conditioning ducts.

Guided by a reductionist logic we have broken down the complexity of the city into neat categories and 'ghettoised' the city into function specific zones - central business districts, dormitory suburbs, industrial parks, shopping malls etc. The result has been a proliferation of high rise, high tech and low density cities which "have become socially divisive, and environmentally hazardous." 3

Having placed our faith in technology, we continue to believe that the miracle of science will deliver all mankind into the promised land, the material paradise. We have been sailing the ship of prosperity, oblivious to the devastation that has followed in its wake.

Today, faced with global warming, destruction of the Earth's nonrenewable resources, the depletion of its rain forests, the degradation of its soil, the pollution of its atmosphere, no less than the burgeoning urban crisis, more and more individuals, non-government organisations, and even "development" and criteria for "progress" measured in terms of material quantities: gross national products, per-capita incomes etc. Sustainability, environmental impact and quality of life, are some of the criteria that have already gained acceptance in development thinking. In the quest for alternative paradigms traditional wisdoms are being seriously studied in many fields.

While "re-interpreting - re-inventing - the dense and diverse urban city, the compact city of overlapping activity," Sir Richard uses the traditional historic city, with its human scale and opportunities for social interaction as a point of reference. Similar approaches have been advocated from as early as the 1940s by Hassan Fathy, and over the last twenty years by others, particularly in the Third World: Kamran Diba (Shushtar New Town, 1975 78); Balkrishna V Doshi (Aranya project, Indore, 1983-86; Vidyadharnagar, Jaipur, 1984-86), and Charles Correa (Belapur Housing, New Bombay, 1985 ?); and my own practice (Lahore Urban Development and Traffic Study, 1980).

Despite having been adopted as official policy, our proposals for Lahore have not been implemented by the Development Authority beyond the one pilot project (Gujjarpura, which after more than fifteen years still remains only partially completed). This fact is a reminder that it takes more than ingenious urban development models, novel structures and clever building

\footnotetext{
${ }^{3}$ Sir Richard Rogers, “Cities for a Small Planet”, BBC Radio 4: the 1995 Reith Lectures.
} 
systems to bring about meaningful change on the ground. The task will require a concerted effort on many fronts: economic and political empowerment, the community's control over its own resources; devolution of power and responsive governance; raising consciousness and awareness of issues related to the environment, health, education, human rights; and community participation, but above all, a redefinition of goals and criteria for 'development" and redefining the meaning of "progress." 